\title{
Tomasz Herodowicz
}

Uniwersytet im. Adama Mickiewicza w Poznaniu

Wydziat Nauk Geograficznych $i$ Geologicznych

e-mail: tomasz.herodowicz@amu.edu.pl

\section{Wpływ polityki spójności na realizację celów środowiskowych Strategii Europa 2020 na przykładzie Poznania}

\begin{abstract}
Zarys treści: Celem artykułu jest $z$ jednej strony przedstawienie znaczenia funduszy strukturalnych i Funduszu Spójności dla rozwiązywania problemów środowiskowych miasta Poznania i jego rozwoju w latach 2004-2014, a z drugiej określenie, jak działania podejmowane $\mathrm{w}$ mieście, współfinansowane $\mathrm{z}$ budżetu UE, wpisywały się $\mathrm{w}$ realizację poszczególnych założeń środowiskowych Strategii Europa 2020. W artykule dokonano również analizy porównawczej największych miast Polski pod względem wartości pozyskanych funduszy unijnych $w$ aspekcie ochrony środowiska. Celem tej analizy było ustalenie różnic wśród polskich metropolii dotyczących poziomu efektywności ubiegania się o unijne wsparcie ukierunkowane na poprawę jakości środowiska naturalnego.
\end{abstract}

Słowa kluczowe: fundusze strukturalne, rozwój zrównoważony, ochrona środowiska, Strategia Europa 2020

\section{Wprowadzenie}

W miarę rozwoju myśli ekonomicznej coraz większą uwagę zwracano na kwestie związane ze środowiskiem przyrodniczym. Początkowo środowisko traktowano wyłącznie jako źródło naturalnych czynników produkcji bez zwracania uwagi na problem ich ograniczoności. Z czasem dostrzeżono niekorzystny wpływ nadmiernej dewastacji środowiska na jakość życia ludzi oraz możliwości dalszego rozwoju gospodarczego. Obecnie, w dobie ogromnej popularności koncepcji rozwoju sustensywnego ${ }^{1}$, środowisku naturalnemu przypisuje się bardzo dużą rolę. Dostosowanie się do potrzeb środowiska i maksymalne przeciwdziałanie jego dalszej degradacji to warunki konieczne do osiągnięcia pożądanego rozwoju $\mathrm{w}$ wymiarach społecznym i ekonomicznym (Bosselmann 2008).

1 Rozwój sustensywny jest $\mathrm{w}$ języku polskim powszechnie nazywany rozwojem zrównoważonym, co nie do końca oddaje istotę tego rozwoju. Więcej na ten temat piszą m.in.: Janikowski (2007), Zegar (2007) i Trzepacz (2012). 
Ochrona środowiska stanowi bardzo ważny element polityki Unii Europejskiej, czego odzwierciedleniem są obecnie cele sformułowane w Strategii Europa 2020. Dotyczą one ograniczenia emisji $\mathrm{CO}_{2}$, wzrostu efektywności energetycznej oraz rozwoju wykorzystania odnawialnych źródeł energii. Realizacja tych celów w zasadniczej mierze będzie się odbywać $\mathrm{w}$ wymiarze miejskim. Miasta są obszarami w najwyższym stopniu przyczyniającymi się do postępującej degradacji środowiska, czego zasadniczą przyczyną jest silna koncentracja ludności oraz działalności gospodarczej. Jednocześnie dzięki miastom i skumulowanym w nim kapitałom powstają innowacyjne rozwiązania problemów z zakresu gospodarki niskoemisyjnej².

Celami niniejszego artykułu są: (1) analiza znaczenia funduszy strukturalnych wydatkowanych na terenie miasta Poznania w ramach polityki spójności UE pod kątem realizacji celów środowiskowych Strategii Europa 2020 w latach 20042014 oraz (2) ustalenie różnic wśród polskich metropolii (Gdańsk, Kraków, Łódź, Poznań, Wrocław, Warszawa) dotyczących poziomu efektywności ubiegania się o unijne wsparcie ukierunkowane na poprawę jakości środowiska naturalnego.

Analiza obejmowała opis diagnostyczny poziomu wartości środków unijnych pozyskanych przez poszczególne miasta na działania wpisujące się w założenia środowiskowe Strategii Europa 2020. W celu efektywniejszego porównania wartości te zrelatywizowano, stosując wskaźniki, odnosząc wartość pozyskanych środków do liczby mieszkańców oraz poziomu wydatków inwestycyjnych danego miasta.

\section{Cele środowiskowe Strategii Europa 2020}

Strategia Europa $2020^{3}$ przyjęta w 2010 r. przez Komisję Europejską stanowi odpowiedź Unii Europejskiej na kryzys gospodarczy rozwijający się od 2008 r. Jest to nadrzędny dokument wyznaczający cele i kierunki rozwoju dla całej Unii Europejskiej. Rozwój ten zgodnie z wizją zawartą w Strategii Europa 2020 powinien być inteligentny, zrównoważony oraz sprzyjający włączeniu społecznemu. Owe trzy cechy rozwoju stanowią jednocześnie jego wzajemnie ze sobą powiązane priorytety.

W kontekście prowadzonej analizy zasadne jest skupienie uwagi na priorytecie odnoszącym się do rozwoju zrównoważonego (sustensywnego) rozumianego jako wspieranie gospodarki efektywniej korzystającej z zasobów, bardziej przyjaznej środowisku i bardziej konkurencyjnej. W ramach tego priorytetu sformułowano trzy wymierne cele środowiskowe, nazywane pakietem klimatyczno-energetycznym lub w skrócie pakietem „3 x 20\%”. W ramach tego pakietu Unia Europejska zobowiązała się do:

- ograniczenia emisji dwutlenku węgla o co najmniej $20 \% \mathrm{w}$ porównaniu z poziomem z 1990 r.,

Komunikat Komisji Europejskiej do Parlamentu Europejskiego, Rady, Europejskiego Komitetu Ekonomiczno-Społecznego i Komitetu Regionów Miejski Wymiar Polityki UE - Kluczowe Elementy Agendy Miejskiej UE z dn. 18 lipca 2014, Bruksela.

3 Komunikat Komisji EUROPA 2020 Strategia na rzecz inteligentnego i zrównoważonego rozwoju sprzyjającego włączeniu społecznemu z dn. 3 marca 2010, Bruksela. 
- wzrostu udziału odnawialnych źródeł energii w całkowitym zużyciu energii do $20 \%$,

- wzrostu efektywności wykorzystania energii o $20 \%$.

Głównymi instrumentami finansowymi wspierającymi realizację tych celów, zwłaszcza na terenach zurbanizowanych, są Europejski Fundusz Rozwoju Regionalnego oraz Fundusz Spójności funkcjonujące w ramach unijnej polityki spójności. Bardziej szczegółowe cele tematyczne oraz główne działania, które można finansować ze środków tych funduszy określone zostały w dokumencie zatytułowanym „Elementy wspólnych ram strategicznych na lata 2014-2020”. Każdemu celowi przypisano szereg działań, na podstawie których można określić główne sektory czy też obszary gospodarki zaangażowane w realizację założeń środowiskowych Strategii Europa 2020. Należą do nich: sektor badawczo-rozwojowy, energetyka, transport, gospodarka przestrzenna, gospodarka wodna oraz gospodarka odpadami (patrz tab. 1).

Tabela 1. Cele tematyczne interwencji polityki spójności, główne działania oraz sektory gospodarki najsilniej związane z realizacją założeń środowiskowych Strategii Europa 2020

\begin{tabular}{|c|c|c|}
\hline $\begin{array}{l}\text { Cel tema- } \\
\text { tyczny }\end{array}$ & Główne działanie & $\begin{array}{l}\text { Sektor/obszar } \\
\text { działanlości } \\
\text { gospodarczej }\end{array}$ \\
\hline \multirow{6}{*}{ 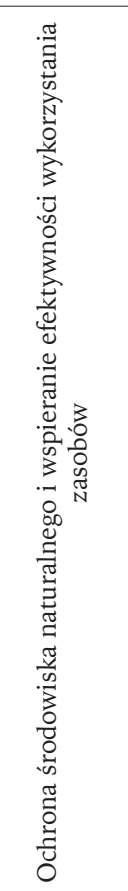 } & $\begin{array}{l}\text { Inwestycje w zakresie efektywnego zaopatrzenia w wodę, oczyszczania ście- } \\
\text { ków i ponownego wykorzystania wody, w tym nowe inwestycje w zakresie } \\
\text { ograniczania wycieków i wdrażania planów gospodarowania wodami w do- } \\
\text { rzeczu }\end{array}$ & $\begin{array}{l}\text { Gospodarka } \\
\text { wodna }\end{array}$ \\
\hline & $\begin{array}{l}\text { Inwestycje } \mathrm{w} \text { zakresie gospodarowania odpadami zgodnie } \mathrm{z} \text { hierarchią } \\
\text { gospodarowania odpadami, w szczególności w zakresie ponownego uży- } \\
\text { cia, recyklingu i odzysku (w przypadku materiałów nie podlegających } \\
\text { recyklingowi) }\end{array}$ & $\begin{array}{c}\text { Gospodarka } \\
\text { odpadami }\end{array}$ \\
\hline & $\begin{array}{l}\text { Inwestycje w zakresie ekologicznej infrastruktury, w tym obszarów Natura } \\
2000 \text { i innych terytoriów, służące promowaniu ochrony i przywracania róż- } \\
\text { norodności biologicznej i usług ekosystemowych, łagodzenia zmian klimatu } \\
\text { i przystosowywania się do nich, ochrony przeciwpowodziowej i przeciwpo- } \\
\text { żarowej, ochrony wybrzeża, ochrony gleb i innych środków zapobiegania } \\
\text { zagrożeniom, zmniejszeniu rozdrobnienia obszarów przyrodniczych; zwięk- } \\
\text { szaniu dostępności wody oraz przywracaniu do właściwego stanu silnie } \\
\text { zmienionych obszarów i siedlisk }\end{array}$ & $\begin{array}{l}\text { Gospodarka } \\
\text { przestrzenna }\end{array}$ \\
\hline & $\begin{array}{l}\text { Inwestycje w działania służące zmniejszeniu zanieczyszczeń powietrza zwią- } \\
\text { zanych z transportem, w szczególności programy wyposażenia i wymiany } \\
\text { flot autobusowych, programy zachęt na rzecz bardziej ekologicznego trans- } \\
\text { portu publicznego i promowania alternatywnych form transportu }\end{array}$ & Transport \\
\hline & $\begin{array}{l}\text { Inwestycje w zakresie dywersyfikacji lokalnych gospodarek poprzez } \\
\text { ochronę i wspieranie dziedzictwa kulturowego i krajobrazów (zarówno } \\
\text { w wiejskim, jak i miejskim kontekście) }\end{array}$ & $\begin{array}{l}\text { Gospodarka } \\
\text { przestrzenna }\end{array}$ \\
\hline & $\begin{array}{l}\text { Wsparcie na rzecz zrównoważonego, zintegrowanego rozwoju miast, m.in. } \\
\text { poprzez środki na rzecz zrównoważonego drenażu miejskiego i likwidowa- } \\
\text { nia zasklepiania gleb, rekultywację obszarów zanieczyszczonych oraz rewi- } \\
\text { talizację infrastruktury kulturalnej }\end{array}$ & $\begin{array}{l}\text { Gospodarka } \\
\text { przestrzenna }\end{array}$ \\
\hline
\end{tabular}

4 Dokument Roboczy Służb Komisji, Elementy wspólnych ram strategicznych na lata 2014-2020, cz. II z dn. 14 marca 2012, Bruksela. 


\begin{tabular}{|c|c|c|}
\hline $\begin{array}{l}\text { Cel tema- } \\
\text { tyczny }\end{array}$ & Główne działanie & $\begin{array}{l}\text { Sektor/obszar } \\
\text { działanlości } \\
\text { gospodarczej }\end{array}$ \\
\hline \multirow{5}{*}{ 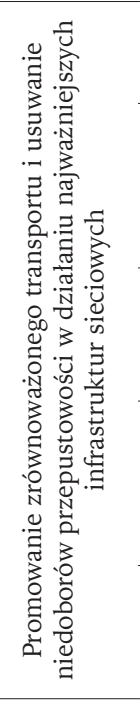 } & $\begin{array}{l}\text { Bazowa infrastruktura transeuropejskich sieci transportowych (TEN-T) } \\
\text { obejmująca transport drogowy, kolejowy, morski oraz multimodalne i inter- } \\
\text { operacyjne środki przynoszące znaczne korzyści netto dla społeczeństwa }\end{array}$ & Transport \\
\hline & $\begin{array}{l}\text { Bazowa infrastruktura kolejowa TEN-T, łączność wtórna, modernizacja gę- } \\
\text { stych sieci kolejowych, europejski system zarządzania ruchem kolejowym } \\
\text { (ERTMS) oraz inne inwestycje służące poprawie interoperacyjności, a także } \\
\text { budowanie potencjału w zakresie planowania i realizowania projektów i za- } \\
\text { rządzania nimi, jak również w zakresie zarządzania ryzykiem i katastrofami }\end{array}$ & Transport \\
\hline & $\begin{array}{l}\text { Innowacyjne ustalanie cen użytkowania dróg, systemy nakładania opłat na } \\
\text { użytkowników i zarządzanie ruchem, infrastruktura do uzupełniania paliwa } \\
\text { i ładowania baterii dla nowych pojazdów bezemisyjnych przeznaczonych do } \\
\text { transportu miejskiego }\end{array}$ & $\begin{array}{l}\text { Badania i roz- } \\
\text { wój }\end{array}$ \\
\hline & $\begin{array}{l}\text { Zintegrowane, zrównoważone i dostępne rozwiązania w zakresie mobil- } \\
\text { ności w miastach, regionach miejskich i na obszarach metropolitalnych, } \\
\text { prowadzące do zmniejszenia emisji gazów cieplarnianych, w szczególności } \\
\text { w ramach planów zrównoważonego transportu miejskiego, w których prze- } \\
\text { widuje się ułatwienia dla transportu publicznego, rowerzystów i pieszych }\end{array}$ & Transport \\
\hline & $\begin{array}{l}\text { Usuwanie niedoborów przepustowości śródlądowych dróg wodnych, przy } \\
\text { jednoczesnej minimalizacji znacznych zmian koryt rzek oraz wspieranie in- } \\
\text { westycji na rzecz bardziej przyjaznych dla środowiska flot i inwestowanie } \\
\text { w systemy informacji żeglugi rzecznej }\end{array}$ & Transport \\
\hline \multirow{5}{*}{ 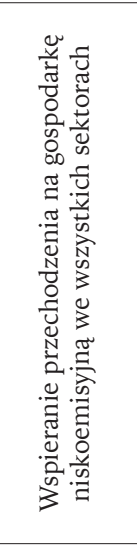 } & $\begin{array}{l}\text { Efektywność energetyczna oraz ogrzewanie i chłodzenie z wykorzystaniem } \\
\text { odnawialnych źródeł energii w budynkach publicznych, w szczególności de- } \\
\text { monstracja budynków o zerowym poziomie emisji i pozytywnym bilansie } \\
\text { energetycznym, jak również dogłębna renowacja istniejących budynków do } \\
\text { poziomów o optymalnych kosztach }\end{array}$ & Energetyka \\
\hline & $\begin{array}{l}\text { Środki na rzecz efektywności energetycznej oraz wykorzystanie odnawial- } \\
\text { nych źródeł energii w MŚP (w tym kampanie informacyjne) }\end{array}$ & Energetyka \\
\hline & $\begin{array}{l}\text { Innowacyjne technologie w zakresie energii odnawialnej, zwłaszcza wymie- } \\
\text { nione w strategicznym planie w dziedzinie technologii energetycznych i pla- } \\
\text { nie działania w dziedzinie energii na rok } 2050 \text { oraz wykorzystanie biopaliw } \\
\text { drugiej i trzeciej generacji }\end{array}$ & $\begin{array}{l}\text { Energetyka, } \\
\text { badania i roz- } \\
\text { wój }\end{array}$ \\
\hline & $\begin{array}{l}\text { Wspieranie produkcji energii z odnawialnych źródeł morskich, w tym ener- } \\
\text { gii pływów i fal }\end{array}$ & Energetyka \\
\hline & $\begin{array}{l}\text { Zintegrowane strategie rozwoju niskoemisyjnego oraz plany działania na } \\
\text { rzecz zrównoważonej energii w odniesieniu do obszarów miejskich, w tym } \\
\text { systemy oświetlenia miejskiego oraz inteligentne sieci }\end{array}$ & Energetyka \\
\hline \multirow{2}{*}{ 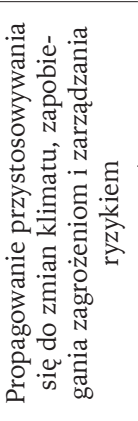 } & $\begin{array}{l}\text { Opracowanie strategii i planów działania dotyczących przystosowania do } \\
\text { zmian klimatu oraz planów zapobiegania zagrożeniom i zarządzania ryzy- } \\
\text { kiem na poziomie krajowym, regionalnym i lokalnym, jak również planów } \\
\text { i strategii dotyczących budowania bazy wiedzy, możliwości monitorowania } \\
\text { danych oraz mechanizmów wymiany informacji }\end{array}$ & $\begin{array}{l}\text { Badania i roz- } \\
\text { wój }\end{array}$ \\
\hline & $\begin{array}{l}\text { Zwiększenie poziomu inwestycji w zakresie przystosowania się do zmian } \\
\text { klimatu oraz zapobiegania zagrożeniom i zarządzania ryzykiem, w tym } \\
\text { w zakresie: zapobiegania zniszczeniom i zwiększania odporności środowi- } \\
\text { ska zabudowanego i innych elementów infrastruktury, ochrony zdrowia lu- } \\
\text { dzi, zmniejszenia presji w odniesieniu do wykorzystania zasobów wodnych } \\
\text { w przyszłości, inwestowania w środki ochrony przeciwpowodziowej i przy- } \\
\text { brzeżnej oraz zmniejszenia podatności ekosystemów w celu zwiększenia ich } \\
\text { odporności i umożliwienia adaptacji w ramach ekosystemów }\end{array}$ & $\begin{array}{l}\text { Gospodarka } \\
\text { przestrzenna, } \\
\text { gospodarka } \\
\text { wodna }\end{array}$ \\
\hline
\end{tabular}




\begin{tabular}{clc}
\hline $\begin{array}{c}\text { Cel tema- } \\
\text { tyczny }\end{array}$ & Glówne działanie & $\begin{array}{c}\text { Sektor/obszar } \\
\text { działanlości } \\
\text { gospodarczej }\end{array}$ \\
\hline & & \\
& & \\
& & \\
& & \\
\end{tabular}

Źródło: opracowanie własne na podstawie „Dokumentu Roboczego Służb Komisji. Elementy wspólnych ram strategicznych na lata 2014-2020".

Katalog działań wspieranych przez politykę spójności jest bardzo szeroki. Duża część z nich związana jest ściśle z obszarami miejskimi. Istotnym jest jednak, aby propozycje działań określone przez UE znalazły odzwierciedlenie w rzeczywistych potrzebach miast i przyczyniały się do realizacji ich środowiskowych celów rozwoju.

\section{Problemy środowiskowe miasta Poznania w okresie 2004-2014}

Miasto Poznań, stolica województwa wielkopolskiego, jak każde duże miasto zmagało się lub nadal zmaga ze znaczącymi problemami związanymi z jakością środowiska przyrodniczego. Analiza miejskich dokumentów programowych i strategicznych ${ }^{5}$ pozwoliła stwierdzić, że największymi problemami Poznania w zakresie ochrony środowiska w ciągu ostatnich dziesięciu lat było zagrożenie hałasem komunikacyjnym oraz zanieczyszczenie wód powierzchniowych. Do pozostałych problemów środowiskowych Poznania zaliczano:

1. Obciążenie środowiska odpadami, zwłaszcza komunalnymi - w tym stanowiącymi pozostałość po dawnych, nielegalnych wysypiskach.

2. Problemy bezpieczeństwa chemicznego (związane m.in. z transportem i składowaniem substancji niebezpiecznych) i zagrożenia związane z ekstremalnymi zjawiskami atmosferycznymi (susze i powodzie).

5 Uchwała nr LVI/592/IV/2004 Rady Miasta Poznania z dnia 23 listopada 2004 r. ws. Planu Rozwoju Miasta Poznania na lata 2005-2010;

Uchwała nr LXXII/990/V/2010 Rady Miasta Poznania z dnia 11 maja 2010 r. ws. Strategii Rozwoju Miasta Poznania do roku 2030;

Uchwała nr XLVII/500/IV/2004 Rady Miasta Poznania z dnia 22 czerwca 2004 r. ws. Programu Ochrony Środowiska dla Miasta Poznania na lata 2004-2007;

Uchwała nr LIV/729/V/2009 Rady Miasta Poznania z dnia 12 maja 2009 r. ws. Programu Ochrony Środowiska dla Miasta Poznania na lata 2009-2012. 
3. Potrzebę ochrony i odbudowy zieleni urządzonej - parki, drzewostany przyuliczne, zieleńce.

4. Zagrożenie jakości i odnawialności zasobów wód podziemnych.

5. Zagrożenie różnorodności biologicznej m.in. poprzez fragmentację przestrzeni przyrodniczej.

6. Degradację gleb, zwłaszcza w związku z postępującą urbanizacją.

7. Zagrożenie jakości powietrza w śródmiejskich dzielnicach (emisja niska) i przy głównych ciągach komunikacyjnych (emisja komunikacyjna).

8. Zagrożenie degradacją powierzchni ziemi związane z bieżącym, nielegalnym składowaniem odpadów, podwyższaniem terenu i nielegalnym pozyskiwaniem kopalin.

9. Promieniowanie niejonizujące.

Są to problemy w większości wciąż aktualne, a konieczność ich rozwiązania została wyrażona w „Strategii Rozwoju Poznania do roku 2030”, w której wyodrębniono cel pośredni: „Ekologiczne i racjonalne gospodarowanie zasobami środowiska i odpadami". W ramach tego celu największym wyzwaniem jest prowadzenie racjonalnej gospodarki zasobami środowiska i odpadami $\mathrm{w}$ sposób zaspokajający potrzeby mieszkańców i jednocześnie cechujący się dbałością o stan środowiska naturalnego. W tym celu zakłada się zrównoważony system gospodarki odpadami oraz budowę odpowiedniej infrastruktury zapewniającej ekologiczną gospodarkę wodami, energią elektryczną, cieplną oraz gazową. Ponadto edukacja ekologiczna i uwarunkowania ekologiczne stanowią stały element wszystkich programów realizowanych w ramach strategii. Bardziej szczegółowe kierunki działań zawierają programy ochrony środowiska dla miasta Poznania, które przedstawiono $\mathrm{w}$ formie tabelarycznej i ze względu na znaczną objętość umieszczono je na końcu niniejszego opracowania (patrz zał. 1).

Porównując główne działania wspierane w ramach polityki spójności z problemami środowiskowymi miasta Poznania oraz kierunkami ich rozwiązywania zauważono ich dużą komplementarność. Pozwala to mieć nadzieję, że w rozpoczynającej się perspektywie finansowej UE Poznań pozyska znaczną ilość środków na rozwiązywanie swoich problemów środowiskowych, wpisując się w realizację celów Strategii Europa 2020. Jednocześnie należy zauważyć, że kierunki środowiskowej interwencji polityki spójności nie pokrywają się z jednym z najważniejszych problemów miasta, czyli zagrożeniem hałasem komunikacyjnym. Brakuje również odniesienia do finansowania projektów związanych $z$ edukacją ekologiczną. 


\section{Wpływ polityki spójności na rozwiązywanie środowiskowych problemów miasta Poznania w latach 2004-2014 w kontekście założeń środowiskowych Strategii Europa 2020}

Badanie zależności między interwencją unijnej polityki spójności a rozwiązywaniem środowiskowych problemów miasta Poznania zostało oparte na danych pochodzących z Systemu Rozliczania Projektów (perspektywa 2004-2006) oraz Krajowego Systemu Informatycznego SIMIK (perspektywa 2007-2013) udostępnionych przez Ministerstwo Infrastruktury i Rozwoju na portalu „Mapa Dotacji UE". Do analizy wybrano projekty z trzech kategorii: ochrony środowiska, transportu i energetyki, uznanych za kluczowe dla realizacji celów rozwoju sustensywnego UE, w tym celów „3 x 20\%”. W przypadku projektów obejmujących obszar większy niż Poznań dokonywano rozszacowywania wartości projektu na wszystkie jednostki terytorialne, w których dany projekt realizowano.

Na terenie Poznania w latach 2004-2014 wykonywanych było 51 projektów współfinansowanych ze środków funduszy strukturalnych i Funduszu Spójności, które wpisywały się w realizację celów środowiskowych Strategii Europa 2020 oraz które były zgodne $z$ aktualnie wyznaczonymi kierunkami interwencji unijnej polityki spójności. Klasyfikacja tych projektów według sektorów czy też obszarów działalności gospodarczej związanych z realizacją celów środowiskowych Strategii Europa 2020, do których zalicza się sektor badawczo-rozwojowy, energetykę, transport, gospodarkę przestrzenną, gospodarkę wodną oraz gospodarkę odpadami, wykazała, że w Poznaniu największy strumień środków finansowych skierowano na działania $z$ sektora transportu, ponad 3 mld zł, z czego prawie połowa pochodziła $z$ budżetu UE. Duży udział pod względem wartości miały również projekty z zakresu gospodarki odpadami, na które pozyskano ponad $350 \mathrm{mln}$ zł, stanowiących około $34 \%$ całkowitej wartości projektów z tej dziedziny. W ramach rozwoju gospodarki wodnej zrealizowano inwestycje o łącznej wartości prawie $700 \mathrm{mln}$ zł, w tym niemal $300 \mathrm{mln}$ zł $(40,5 \%)$ pochodziło z budżetu UE. Wartość projektów związanych z energetyką - efektywnością energetyczną czy

Tabela 2. Obszary działalności gospodarczej wspierane przez fundusze strukturalne w Poznaniu w latach 2004-2014

\begin{tabular}{lrrc}
\hline $\begin{array}{c}\text { Sektor/obszar działalności } \\
\text { gospodarczej }\end{array}$ & $\begin{array}{c}\text { Wartość projektów } \\
{[\mathrm{zł}]}\end{array}$ & $\begin{array}{c}\text { Wartość dofinansowa- } \\
\text { nia UE [zł] }\end{array}$ & $\begin{array}{c}\text { Udział dofinanso- } \\
\text { wania UE w ogólnej } \\
\text { wartości projektów } \\
{[\%]}\end{array}$ \\
\hline Gospodarka wodna & 696376654,86 & 289021838,01 & 41,5 \\
Gospodarka odpadami & 1044477184,39 & 352567900,00 & 33,8 \\
Energetyka & 111572453,56 & 34518025,42 & 30,9 \\
Transport & 3257893666,53 & 1608633209,66 & 49,4 \\
Gospodarka przestrzenna & 1716357,00 & 1195822,50 & 69,7 \\
Suma & 5112036316,34 & 2285936795,59 & 44,7 \\
\hline
\end{tabular}

Źródło: opracowanie własne na podstawie danych z mapadotacji.gov.pl. 
zastosowaniem odnawialnych źródeł energii - przekroczyła 100 mln zł, w tym ponad $1 / 3$ to unijne dofinansowanie. Najmniej środków przekazano na działania w ramach gospodarki przestrzennej, niecałe 2 mln zł. Jednocześnie tę kategorię projektów cechował najwyższy poziom udziału dofinansowania, prawie $70 \%$ (por. tab. 2). Wśród projektów nie udało się wyróżnić takich, które bezpośrednio odnosiły się do sektora badawczo-rozwojowego. Jego udział ma raczej charakter pośredni i można go wiązać ze stosowaniem innowacyjnych rozwiązań i technologii $\mathrm{w}$ transporcie i energetyce.

Inwestycje realizowane $\mathrm{w}$ Poznaniu $\mathrm{w}$ zakresie transportu można podzielić na dwie grupy: inwestycje $w$ infrastrukturę drogową oraz inwestycje $w$ transport zbiorowy. Na projekty dotyczące infrastruktury drogowej pozyskano ponad 540 mln zł, stanowiących ponad $33 \%$ wsparcia skierowanego do sektora transportowego. Natomiast dofinansowanie komunikacji zbiorowej przekroczyło 1 mld zł, czyli przeszło 66\% dofinansowania dla transportu w Poznaniu.

W analizie uwzględniono projekty drogowe, bo choć z jednej strony mogą powodować zwiększony ruch samochodowy, to $z$ drugiej strony zastosowane technologie i rozwiązania organizacji ruchu ograniczają niekorzystne oddziaływanie transportu na środowisko. Tym bardziej, że prawie wszystkie projekty dotyczyły modernizacji lub przebudowy już istniejących ulic czy wiaduktów, a nie budowy nowych, co wpisuje się $\mathrm{w}$ strategiczny kierunek działań polityki spójności odnoszący się do zintegrowanych, zrównoważonych i dostępnych rozwiązań w zakresie mobilności w miastach, regionach miejskich i na obszarach metropolitalnych. Jednocześnie projekty te przyczyniały się do rozwiązywania problemów środowiskowych miasta. Zastosowanie nowoczesnych, cichych nawierzchni drogowych oraz ekranów akustycznych wpływało na zmniejszenie się hałasu komunikacyjnego od 3 do ponad $20 \mathrm{~dB}$. W realizacji projektów drogowych wykazano również dbałość o jakość wód, wprowadzając system podczyszczania wody deszczowej w kanalizacji przed wprowadzeniem jej do odbiorników ${ }^{6}$.

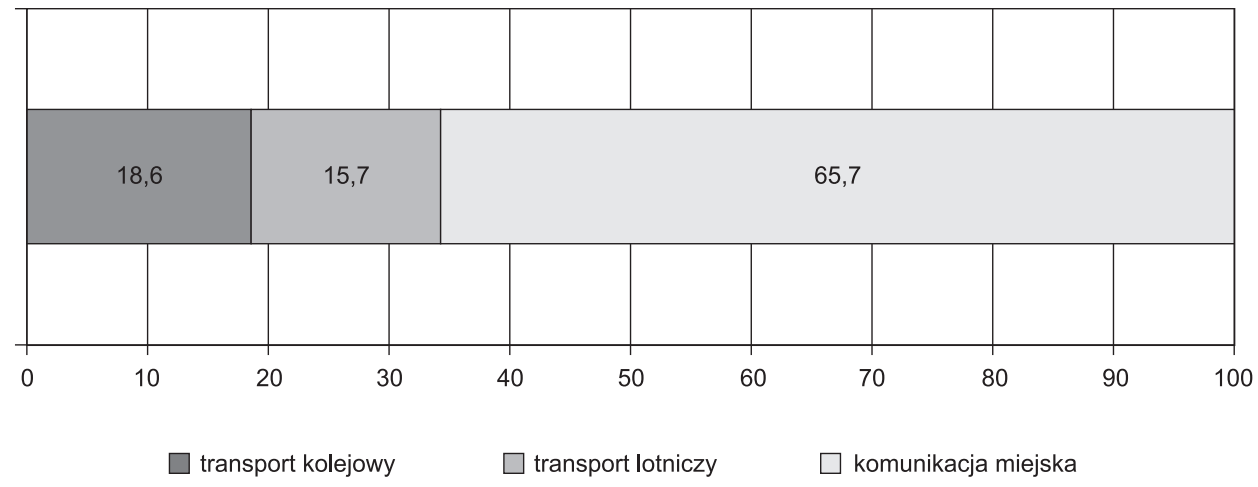

Ryc. 1. Struktura udziałowa wartości projektów wspóffinansowanych w ramach polityki spójności w dziedzinie transportu zbiorowego w Poznaniu w latach 2004-2014 Źródło: opracowanie własne na podstawie danych z mapadotacji.gov.pl.

$6 \quad$ Raport z realizacji Programu Ochrony Środowiska dla Miasta Poznania za lata 2009-2012. 
Projekty z zakresu transportu zbiorowego na terenie Poznania obejmowały transport kolejowy, lotniczy i komunikację miejską. Najwięcej środków, ponad 1,5 mld zł, przeznaczono na inwestycje w komunikację miejską, co stanowiło przeszło $65 \%$ ogólnej wartości projektów w dziedzinie transportu zbiorowego w Poznaniu. W dziedzinie transportu kolejowego zrealizowano projekty o sumie ponad $425 \mathrm{mln}$ zł (udział ponad 18\%). Projekty w zakresie transportu lotniczego wyniosły prawie $360 \mathrm{mln}$ zł, co stanowiło prawie 16\% wartości inwestycji transportu zbiorowego (patrz ryc. 1).

Ogół projektów dotyczących transportu zbiorowego wpisuje się w realizację celu UE dotyczącego ochrony środowiska naturalnego i wspierania efektywności wykorzystanych zasobów. Dzięki inwestycjom promującym alternatywne formy transportu oraz podnoszącym jakość komunikacji miejskiej Poznań przyczynia się do zmniejszenia zanieczyszczeń powietrza. Wśród projektów z tej grupy szczególną uwagę należy zwrócić na bardzo duże przedsięwzięcia wymiany floty tramwajowej i autobusowej. Zakup nowoczesnych, niskopodłogowych tramwajów dla miasta to wartość ponad $380 \mathrm{mln}$ zł, z czego ponad połowa pochodziła z Funduszu Spójności. Dzięki tym środkom po Poznaniu kursuje dzisiaj 45 tramwajów Solaris Tramino, które dzięki nowoczesnej technologii pozwalają na odzyskanie do sieci energii wytworzonej podczas hamowania pojazdu lub zamienienie jej na ciepło do ogrzewania (por. www.solarisbus.com). Natomiast przy udziale środków Europejskiego Funduszu Rozwoju Regionalnego zrealizowano dwuetapowy projekt zakupu nowoczesnych, przyjaznych środowisku autobusów za łączną kwotę prawie $120 \mathrm{mln}$ zł, z czego prawie $63 \%$ pochodziło z UE. W ramach projektu zakupiono 101 autobusów napędzanych ekologicznymi silnikami spełniającymi rygorystyczną europejską normę czystości spalin EEV (por. www. mpk.poznan.pl). Pozostałe znaczące projekty w zakresie transportu zbiorowego realizowane w Poznaniu dotyczą m.in.: rozbudowy sieci torowisk, budowy dworca autobusowego, modernizacji lotniska, modernizacji linii kolejowych czy zakupu taboru dla regionalnych pasażerskich przewozów kolejowych.

Poza omówionymi inwestycjami transportowymi w Poznaniu zrealizowano projekt o charakterze informacyjno-edukacyjnym „»Ecodriving bezpiecznego Poznania" - program dla Wielkopolan, jak chronić środowisko, poprawiać bezpieczeństwo i ekonomię jazdy samochodem" o wartości ponad 300 tys. zł, dofinansowany w prawie 70\% przez Europejski Fundusz Rozwoju Regionalnego. Inicjatywa miała na celu popularyzację nowoczesnej i inteligentnej techniki kierowania samochodem, zmniejszającej obciążenie środowiska i poprawiającej bezpieczeństwo w ruchu drogowym.

W ramach gospodarki odpadami wykonano projekt „System gospodarki odpadami dla miasta Poznania”, którego wartość przekroczyła 1 mld zł, z czego 1/3 pochodziła ze środków Funduszu Spójności. Głównym elementem tego projektu była budowa instalacji do termicznego przekształcania frakcji resztkowej zmieszanych odpadów komunalnych, dzięki której ze spalania odpadów przewiduje się uzyskiwanie około $128000 \mathrm{MWh} /$ rok energii elektrycznej i około 267000 GJ/rok energii cieplnej. W zakresie gospodarki odpadami spółka EKO-ZEC otrzymała unijne dofinansowanie (ponad 0,5 mln zł) na budowę węzła be- 
toniarskiego, która to inwestycja pozwala na produkcję mieszanek betonowych w oparciu o kruszywa recyklingowe, a także popioły i żużel pochodzące ze spalania węgla w poznańskiej elektrociepłowni (por. www.eco-zec.com.pl). Oba projekty w wyraźny sposób wpisują się w aktualne cele UE dotyczące efektywnego zużytkowania zasobów oraz wzrostu wykorzystania energii odnawialnej. Jednocześnie ich realizacja przyczyniła się do rozwiązania jednego z poznańskich problemów środowiskowych - nadmiernego obciążenia środowiska odpadami.

Wsparcie polityki spójności dla działań związanych z gospodarką wodną miasta objęło czteroetapowy projekt „Uporządkowanie gospodarki wodno-ściekowej dla ochrony zasobów wodnych w Poznaniu i okolicach". Wartość projektu realizowanego w Poznaniu (po podziale na powiaty objęte realizacja) wyniosła łącznie prawie 700 mln zł, z czego około $40 \%$ pochodziło z Funduszu Spójności. Projekt obejmował kilkadziesiąt zadań inwestycyjnych, m.in. modernizację przepompowni, hermetyzację oczyszczalni ścieków czy budowę sieci kanalizacyjnej (por. www.inwestycjeunijne.aquanet.pl). Stanowił istotną część działań na terenie miasta mających na celu poprawę jakości wód powierzchniowych, jednocześnie wpisywał się w aktualny trend polityki spójności dotyczący inwestycji w zakresie efektywnego zaopatrzenia w wodę, oczyszczania ścieków i ponownego wykorzystania wody.

W dziedzinie energetyki na terenie Poznania zrealizowano dwa znaczące projekty z zakresu rozwoju wykorzystania odnawialnych źródeł energii oraz siedem projektów związanych z termomodernizacją budynków.

Największą wartość miał projekt „Konwersja kotła OP140 na kocioł fluidalny opalany biomasą w Dalkia Poznań ZEC S.A.”. Wyniosła ona prawie $80 \mathrm{mln}$ zł, w tym ponad $20 \%$ pochodziło z Europejskiego Funduszu Rozwoju Regionalnego. Dzięki inwestycji elektrociepłownia zmniejszyła negatywne oddziaływanie na środowisko poprzez obniżenie wielkości emisji zanieczyszczeń do powietrza: $\mathrm{NO}_{\mathrm{x}}$ o 19,7 ton/rok, pyłów o 24,8 ton/rok, $\mathrm{SO}_{2}$ o 1059,9 ton/rok, a $\mathrm{CO}_{2}$ o 270 892 ton/rok (por. www.mos.gov.pl). Ważny dla rozwoju energetyki odnawialnej w Poznaniu był także projekt „System grzewczy z odnawialnych źródeł energii $z$ instalacją przesyłową przy użyciu pomp ciepła typu solanka/woda dla osiedla Podolany w Poznaniu" o wartości ponad 18 mln zł (wsparcie Europejskiego Funduszu Rozwoju Regionalnego wyniosło mniej więcej 50\%). Jest to pilotażowy w skali województwa projekt wykorzystujący energię geotermalną do ogrzewania osiedla bloków mieszkalnych. Ciepło pobrane z gruntu ogrzewa hotel i sześć budynków mieszczących 284 mieszkania (por. www.instalreporter.pl). Oba przedstawione projekty wpisują się ściśle w realizację celów środowiskowych Strategii Europa 2020 dotyczących przejścia na gospodarkę niskoemisyjną, korzystającą $z$ energii odnawialnej.

Fundusze strukturalne miały również swój udział we wzroście efektywności energetycznej poznańskich budynków użyteczności publicznej. Zmodernizowano szereg obiektów należących do policji, spóldzielni mieszkaniowej oraz ośrodki zdrowia i jednostki naukowe. Łączna wartość tych inwestycji przekroczyła $14 \mathrm{mln}$ zł, z czego ponad połowa pochodziła z budżetu UE. W ramach tych inwestycji ocieplono budynki, wymieniono stolarkę okienną oraz zmodernizowano system 
grzewczy. Oszczędności zużywanej energii są bardzo wymierne, dla przykładu termomodernizacja budynku UE w Poznaniu pozwoliła na zmniejszenie zużycia energii o 59\% (por. www.ue.poznan.pl), a termomodernizacja budynków Poznańskiej Spółdzielni Mieszkaniowej Winogrady pozwoliła na oszczędność energii rzędu 1 621,84 GJ/rok (por. www.wfosgw.poznan.pl). Należy również zwrócić uwagę na fakt, że niektóre projekty obejmowały instalację systemów wykorzystujących energię odnawialną jako dodatkowe źródło energii. Tym samym można stwierdzić, że projekty poznańskie $\mathrm{w}$ zakresie energetyki stanowią wymierny efekt realizacji środowiskowych założeń unijnej strategii dotyczących ograniczenia emisji $\mathrm{CO}_{2}$, wzrostu efektywności energetycznej oraz korzystania z odnawialnej energii.

Ostatnim przedsięwzięciem realizowanym przy wsparciu środków z funduszy strukturalnych $\mathrm{w}$ Poznaniu jest projekt związany z gospodarką przestrzenną dotyczący zagospodarowania obszaru cennego przyrodniczo. Projekt „Ochrona przyrodniczo cennych okolic Poznania przez ukierunkowanie i koncentrację ruchu turystycznego" miał na celu m.in. ochronę poznańskiego Rezerwatu Przyrody „Meteoryt Morasko” przed nadmierną i niekontrolowaną presją ludzi poprzez kanalizację ruchu turystycznego wraz z przygotowaniem infrastruktury działającej jako bufor chroniący pozostałe cenne przyrodniczo obszary przed zadeptaniem. W ramach tego projektu o wartości przekraczającej 1,7 mln zł (w tym prawie $70 \%$ stanowiło wsparcie UE) zbudowano parking wraz z infrastrukturą sanitarną dla turystów. Inwestycja wpisuje się w działanie polityki spójności dotyczące ekologicznej infrastruktury służącej ochronie i przywracaniu różnorodności biologicznej i usług ekosystemowych.

\section{Poznań na tle największych polskich miast pod względem pozyskiwania środków polityki spójności na realizację celów środowiskowych Strategii Europa 2020}

Analiza porównawcza największych polskich miast została przeprowadzona w oparciu o wartości projektów, których beneficjentem była wyłącznie administracja samorządowa bez uwzględnienia projektów realizowanych przez jednostki organizacyjne oraz spółki miejskie. Badaniami objęto następujące miasta: Gdańsk, Kraków, Łódź, Poznań, Warszawę i Wrocław. Zakres czasowy porównania to lata 2004-2013, okres dwóch perspektyw finansowych UE, w których do tej pory funkcjonowała Polska.

Pod względem ogólnej wartości projektów, które wpisywały się w realizację celów środowiskowych Strategii Europa 2020, Poznań zajmował drugą pozycję wśród badanych miast. Wykonano tu przedsięwzięcia za łącznie ponad 2,5 mld zł, z czego mniej niż połowę stanowiły środki funduszy unijnych. Wyższy wynik osiągnęła jedynie Warszawa z projektami na kwotę blisko 9 mld zł, w tym niecałe 4 mld zł pochodziły z budżetu UE. Tak duża różnica była efektem realizowanego w stolicy projektu budowy drugiej linii metra, którego wartość $(5,9$ mld zł) przekracza połowę wartości ogółu tamtejszych projektów. Samorządy 


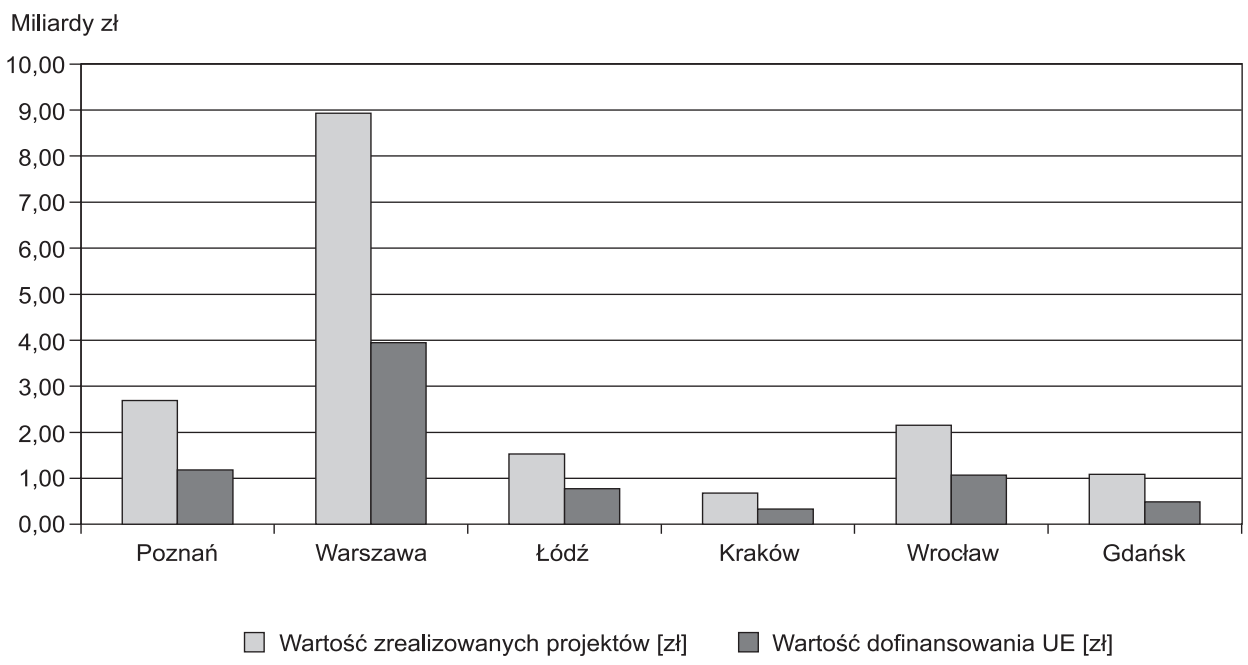

Ryc. 2. Łączna wartość projektów związanych z osiąganiem celów środowiskowych Strategii Europa 2020 wspieranych przez budżet UE zrealizowanych przez największe miasta w Polsce w latach 2004-2013

Źródło: opracowanie własne na podstawie danych z mapadotacji.gov.pl.

pozostałych miast zrealizowały projekty o łącznej wartości w przedziale od 0,7 do 2,1 mld zł (patrz ryc. 2).

Spore różnice między miastami w bezwzględnej wartości projektów ulegają znacznemu zatarciu po odniesieniu wartości bezwzględnych do liczby mieszkańców danego miasta. Warszawa i Poznań charakteryzowały się podobnymi, największymi wartościami badanego wskaźnika. Na jednego mieszkańca tych miast przypadało około 5000 zł ogólnej wartości zrealizowanych projektów, z czego mniej więcej 2000 zł pochodziło z funduszy unijnych. W pozostałych miastach notowane wartości były znacząco niższe. We Wrocławiu wartość zrealizowanych projektów per capita wyniosła ponad 3400 zł, w Gdańsku i Łodzi około 2000 zł. Kraków na tle pozostałych miast wypadł zdecydowanie najsłabiej. Na jednego mieszkańca przypadało tu kilkakrotnie mniej środków niż w Warszawie czy Poznaniu (patrz ryc. 3).

W analizie porównawczej wykorzystano również wskaźnik udziału wartości zrealizowanych projektów w wydatkach inwestycyjnych majątkowych samorządów. W Warszawie wartość tego wskaźnika wyniosła ponad 56\%, a w Poznaniu ponad $50 \%$. Dla Łodzi i Wrocławia wartość inwestycji dofinansowanych przez środki funduszy strukturalnych to około 35\% wydatków inwestycyjnych. Z kolei najniższe wartości odnotowano w Gdańsku i Krakowie, odpowiednio 26\% i $15 \%$ (patrz ryc. 4). Wysokie udziały wartości zrealizowanych projektów, przekraczające często 1/3 ogółu majątkowych wydatków inwestycyjnych, pozwalają stwierdzić, że wsparcie unijnej polityki spójności w zakresie celów środowiskowych Strategii Europa 2020 stanowi bardzo istotny czynnik realizacji celów środowiskowych polskich metropolii. Warto jednocześnie zauważyć, że udział samych środków pochodzących z budżetu UE jest bardzo znaczący szczególnie 


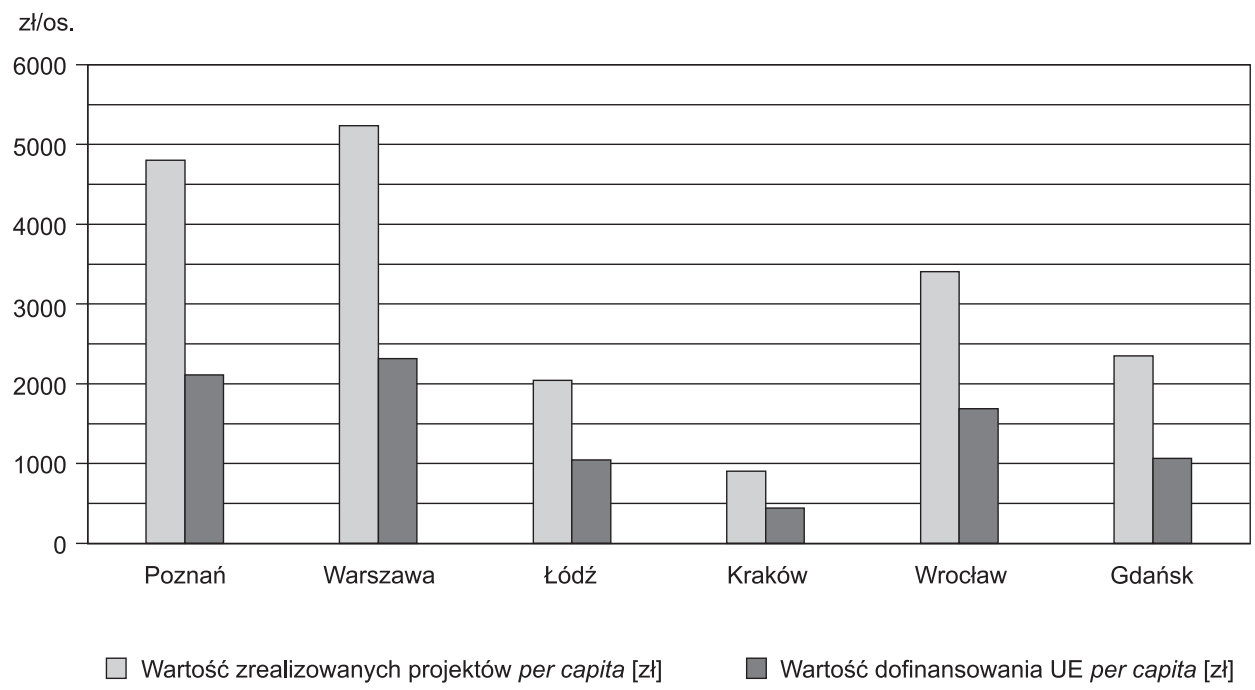

Ryc. 3. Wartość projektów związanych z osiąganiem celów środowiskowych Strategii Europa 2020 wspieranych przez budżet UE przypadająca na mieszkańca w największych miastach Polski w latach 2004-2013

Źródło: opracowanie własne na podstawie danych z mapadotacji.gov.pl oraz BDL (2014).

w wydatkach Poznania, Warszawy i Łodzi, gdzie kształtuje się on w okolicach $20 \%$ (patrz ryc. 4 ).

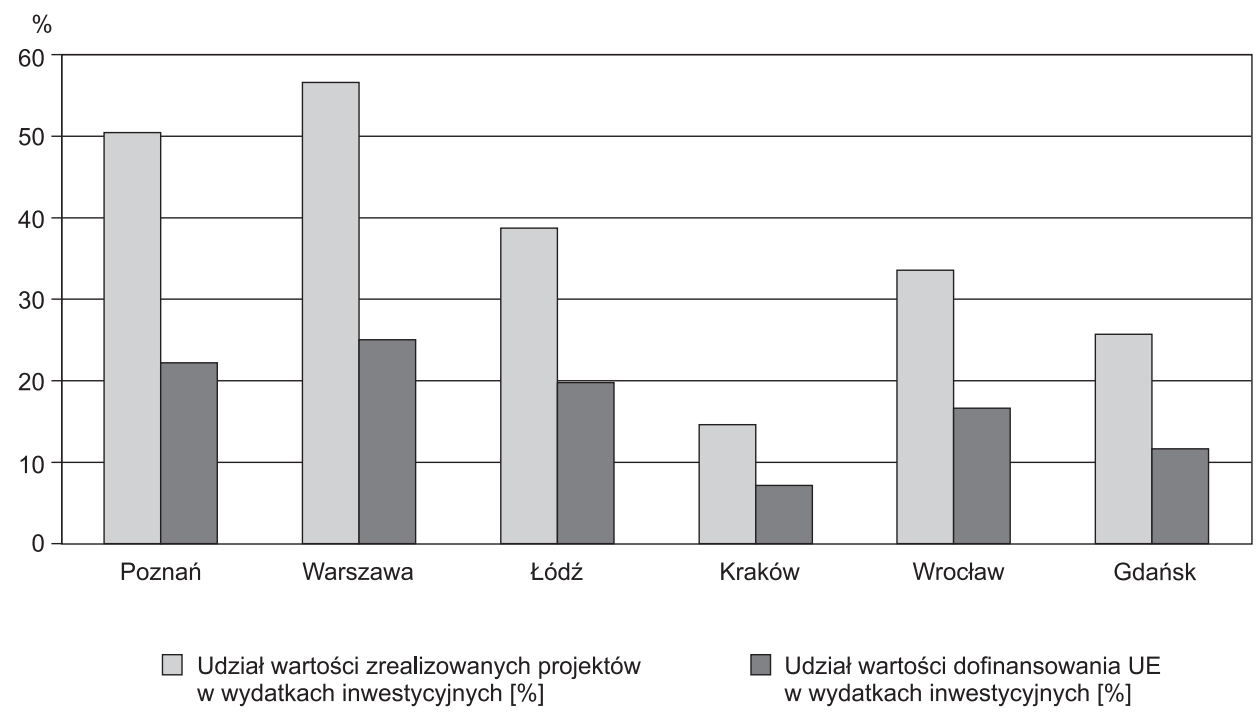

Ryc. 4. Udział wartości projektów związanych z osiąganiem celów środowiskowych Strategii Europa 2020 wspieranych przez budżet UE w wydatkach inwestycyjnych największych polskich miast w latach 2004-2013

Źródło: opracowanie własne na podstawie danych z mapadotacji.gov.pl oraz BDL (2014). 


\section{Podsumowanie}

Unia Europejska przypisuje środowisku przyrodniczemu bardzo duże znaczenie w kształtowaniu rozwoju społeczno-gospodarczego, czego wyrazem są cele „3 x 20\%” sformułowane w Strategii Europa 2020 oraz kierunki działań wytyczone dla polityki spójności na najbliższe lata. Realizacja unijnych założeń odbywa się głównie w pięciu obszarach działalności gospodarczej: transporcie, energetyce, gospodarce wodnej, gospodarce odpadami, sektorze badawczo-rozwojowym oraz gospodarce przestrzennej. Znaczącą rolę w osiąganiu celów środowiskowych odgrywają miasta, to one borykają się z największymi problemami środowiskowymi, a jednocześnie są miejscami powstawania innowacyjnych rozwiązań tych problemów. Sytuacja ta tłumaczy silne przestrzenne ukierunkowanie interwencji polityki spójności właśnie na obszary metropolitalne.

Na terenie miasta Poznania, jednej z największych aglomeracji Polski, w latach 2004-2014 zidentyfikowano szereg problemów środowiskowych. Najważniejsze $z$ nich dotyczyły ponadnormatywnego przekraczania norm hałasu komunikacyjnego oraz zanieczyszczeń wód powierzchniowych. Ponadto wśród wyzwań środowiskowych miasta znalazło się m.in. obciążenie środowiska odpadami oraz zagrożenie jakości powietrza. Problemy te najsilniej korespondują z założeniami wyznaczonymi w Strategii Europa 2020. W celu ich niwelowania w Poznaniu pozyskano łącznie ponad 2,2 mld zł unijnego wsparcia, co stanowi mniej więcej $1 / 3$ całkowitej kwoty poznańskiej absorpcji środków UE. Najsilniej wspieranymi dziedzinami gospodarki w zakresie rozwiązywania problemów środowiskowych miasta były transport oraz gospodarka odpadami. Charakterystyka projektów realizowanych na terenie Poznania wykazała dużą różnorodność działań podejmowanych w celu poprawy jakości środowiska przyrodniczego. Od rozbudowy infrastruktury komunikacji zbiorowej, przez wymianę taboru na bardziej energooszczędny, wprowadzanie technologii korzystających z odnawialnych źródeł energii, termomodernizację budynków, inwestycje z zakresu gospodarki wodno-ściekowej, aż do ochrony obszarów cennych przyrodniczo. Niestety żaden z projektów nie dotyczył wytworzenia czy rozwijania nowoczesnych technologii zmniejszających negatywne oddziaływanie człowieka na środowisko. Wynikać to może $z$ relatywnie niskiego poziomu innowacyjności w stosunku do rozwiniętych zachodnioeuropejskich ośrodków miejskich i faktu, że gospodarka oparta na wiedzy w Poznaniu jest dopiero budowana (Gaczek 2009).

Porównanie największych miast Polski pod względem wartości pozyskanych środków na realizację działań wpisujących się w cele środowiskowe Strategii Europa 2020 wykazało, że Poznań plasuje się w ścisłej czołówce, zaraz za Warszawą. Potwierdziła to zarówno analiza danych bezwzględnych, jak i zrelatywizowanych. Fundusze polityki spójności pozyskane na działania służące realizacji unijnych celów środowiskowych na terenie Poznania miały znaczący wkład w kształtowanie rozwoju miasta, czego wyrazem jest ich udział w wydatkach inwestycyjnych kształtujący się na poziomie przekraczającym $20 \%$.

Wysoka pozycja Poznania, którą samorząd wypracował w okresie 2004-2014, stanowi dobry prognostyk na zbliżające się lata, kiedy na działania związane 
z ochroną środowiska i przechodzeniem na gospodarkę niskoemisyjną przewidziane zostaną z pewnością znaczniejsze środki finansowe niż w latach ubiegłych. Poznań powinien ubiegać się o środki unijne szczególnie w celu ograniczenia tzw. emisji niskiej, która stanowi główną przyczynę przekraczania norm stężenia pyłów, zwłaszcza w okresie grzewczym. Istotne jest także stymulowanie rozwoju innowacji w zakresie gospodarki niskoemisyjnej, efektywności energetycznej oraz odnawialnych źródeł energii. Mimo że klimat akustyczny miasta poprawił się w ciągu ostatnich lat, to należy również podejmować dalsze kroki w celu ograniczania niekorzystnego wpływu hałasu na jakość życia w mieście.

\section{Literatura}

Bosselmann K. 2008. Principle of Sustainability: Transforming Law and Governance. Ashgate Publishing Group, Abingdon.

Dokument Roboczy Służb Komisji. 2012. Elementy wspólnych ram strategicznych na lata 2014-2020. Cz. II z dn. 14 marca 2012, Bruksela.

Gaczek W.M. 2009. Gospodarka oparta na wiedzy w Poznaniu. Uniwersytet Ekonomiczny w Poznaniu, Poznań.

Janikowski R., 2007. Sustensologia, a zrównoważony rozwój. [W:] B. Poskrobko, G. Dobrzański (red.), Problemy interpretacji i realizacji zrównoważonego rozwoju. Wydawnictwo Wyższej Szkoły Ekonomicznej w Białymstoku, Białystok, s. 49-56.

Komunikat Komisji EUROPA 2020. 2010. Strategia na rzecz inteligentnego i zrównoważonego rozwoju sprzyjającego włączeniu społecznemu z dn. 3 marca 2010, Bruksela.

Komunikat Komisji Europejskiej do Parlamentu Europejskiego, Rady, Europejskiego Komitetu Ekonomiczno-Społecznego i Komitetu Regionów Miejski Wymiar Polityki UE - Kluczowe Elementy Agendy Miejskiej UE z dn. 18 lipca 2014, Bruksela.

Parysek J.J. 2007. Wprowadzenie do gospodarki przestrzennej. Wydawnictwo Naukowe Uniwersytetu im. Adama Mickiewicza w Poznaniu, Poznań.

Raport z realizacji Programu Ochrony Środowiska dla Miasta Poznania za lata 2009-2012.

Trzepacz P. 2012. Geneza i istota koncepcji rozwoju zrównoważonego. [W:] P. Trzepacz (red.), Zrównoważony rozwój - wyzwania globalne. Wydawca Instytut Geografii i Gospodarki Przestrzennej UJ, Kraków, s. 11-35.

Uchwała nr XLVII/500/IV/2004 Rady Miasta Poznania z dnia 22 czerwca 2004 r. ws. Programu Ochrony Środowiska dla Miasta Poznania na lata 2004-2007.

Uchwała nr LIV/729/V/2009 Rady Miasta Poznania z dnia 12 maja 2009 r. ws. Programu Ochrony Środowiska dla Miasta Poznania na lata 2009-2012.

Uchwała nr LVI/592/IV/2004 Rady Miasta Poznania z dnia 23 listopada 2004 r. ws. Planu Rozwoju Miasta Poznania na lata 2005-2010.

Uchwała nr LXXII/990/V/2010 Rady Miasta Poznania z dnia 11 maja 2010 r. ws. Strategii Rozwoju Miasta Poznania do roku 2030.

Zegar J.S. 2007. Podstawowe zagadnienia rozwoju zrównoważonego, Wydawnictwo Wyższej Szkoły Bankowości i Finansów w Bielsku-Białej, Bielsko-Biała.

\section{Strony internetowe}

Aquanet i UE wspólne inwestycje, pobrano 11.09.2014 r.,

http://inwestycjeunijne.aquanet.pl/o-projekcie

Portal Spółki EKO-ZEC, pobrano 3.09.2014 r.,

http://www.eko-zec.com.pl/nasza-oferta/produkty/popiol-lotny-i-zuzel.html

Instalreporter - bezpłatny magazyn branży instalacyjnej, pobrano 3.09.14 r.,

http://instalreporter.pl/ogolna/pompy-ciepla-stiebel-eltron-na-najwiekszej-inwestycji-w-polscewykorzystujacej-oze/ 
Ministerstwo środowiska, pobrano 3.09.2014 r.,

http://www.mos.gov.pl/artykul/70_infrastruktura_i_srodowisko/18724_zielona_energia_z_elektrowni_w_opolu_i_elektrocieplowni_w_poznaniu.html

Miejskie Przedsiębiorstwo Komunikacyjne w Poznaniu, pobrano 2.09.2014 r.,

http://www.mpk.poznan.pl/o-mpk/tabor/120-tabor-autobusowy/1883-solaris-urbino-8-6

Solaris Bus and Coach S.A., pobrano 2.09.2014 r.,

http://www.solarisbus.com/vehicles_group/tramino

Uniwersytet Ekonomiczny w Poznaniu, pobrano 3.09.2014 r.,

http://ue.poznan.pl/en/uniwersytet,c13/administracja,c29/administracyjny-pion-organizacyjnyprorektora-ds-strategii-i-rozwoju,c51/biuro-pozyskiwania-funduszy,c1350/projekty-zrealizowane,c2018/termomodernizacja-budynku-dydaktyczno-naukowego-c,a14886.html

Wojewódzki Fundusz Ochrony Środowiska i Gospodarki Wodnej w Poznaniu, pobrano 3.09.2014 r., http://www.wfosgw.poznan.pl/strona-glowna/obiekty-publiczne-poznanskiej-spoldzielnimieszkaniowej-bdquo-winogrady-rdquo-wpisaly-sie-w-strategie-oszczedzania-energii.html

\title{
The impact of cohesion policy on realization the environmental objectives of the Europe 2020 Strategy on the example of Poznan
}

\begin{abstract}
The aim of this article is to present the significance of structural funds for the implementation of the environmental objectives of the Europe 2020 Strategy in Poznan for the years 2004-2014. In the first part of the paper were presented current EU environmental objectives and directions of cohesion policy intervention. Then there was presentation of the environmental problems of Poznan. In the next part of the article there was included analysis of the links between projects implemented with participation in structural funds and environmental problems of Poznan and the aims of Europe 2020 Strategy. At the last stage of the analysis, there was a comparison of the largest Polish cities in terms of the value gained funds, which allowed to assess the importance of EU intervention for actions taken by local government to stimulate the socio-economic development in environmental aspect.
\end{abstract}

Key words: environment protection, Europe 2020 Strategy, Structural Funds, sustainable development

Załącznik 1. Kierunki działań Poznania w celu rozwiązywania problemów środowiskowych miasta w okresie 10 lat integracji z UE

\begin{tabular}{|c|c|}
\hline \multirow{5}{*}{ 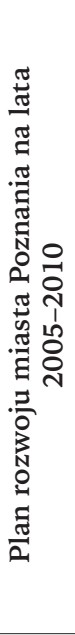 } & Priorytetowe kierunki działań \\
\hline & $\begin{array}{l}\text { Zmniejszenie uciążliwości spowodowanych hałasem komunikacyjnym (promowanie nowo- } \\
\text { czesnych rozwiązań technologicznych i technicznych przy modernizacji i budowie infra- } \\
\text { struktury transportowej, promowanie ekologicznych środków transportu, budowa ekranów } \\
\text { akustycznych celem ochrony zagrożonych hałasem obszarów miasta) }\end{array}$ \\
\hline & $\begin{array}{l}\text { Przywracanie i stabilizacja stanu czystości wód cieków i zbiorników wodnych na terenie } \\
\text { miasta do wymogów określonych w aktualnie obowiązujących przepisach (zwiększenie } \\
\text { przepustowości kolektorów doprowadzających ścieki do Centralnej Oczyszczalni Ścieków, } \\
\text { przebudowa newralgicznych punktów systemu kanalizacji miejskiej celem uniemożliwienia } \\
\text { przelewu ścieków do wód powierzchniowych, zwiększenie dostępności mieszkańców do } \\
\text { sieci wodociągowej i kanalizacyjnej) }\end{array}$ \\
\hline & $\begin{array}{l}\text { Doskonalenie systemu gospodarowania odpadami komunalnymi (upowszechnienie idei } \\
\text { segregacji odpadów i wtórnego ich wykorzystania, stworzenie systemu bezpiecznego pozby- } \\
\text { wania się odpadów niebezpiecznych wraz z Punktami Odpadów Problemowych, moderniza- } \\
\text { cja składowiska w Suchym Lesie, rekultywacja obszarów zdegradowanych) }\end{array}$ \\
\hline & $\begin{array}{l}\text { Rozwój, zwiększenie atrakcyjności oraz ochrona terenów zielonych w mieście (renowacja } \\
\text { pasów zieleni przydrożnej, budowa nowych i renowacja istniejących terenów zieleni, ochro- } \\
\text { na zasobów leśnych i korytarzy przyrodniczych) }\end{array}$ \\
\hline
\end{tabular}




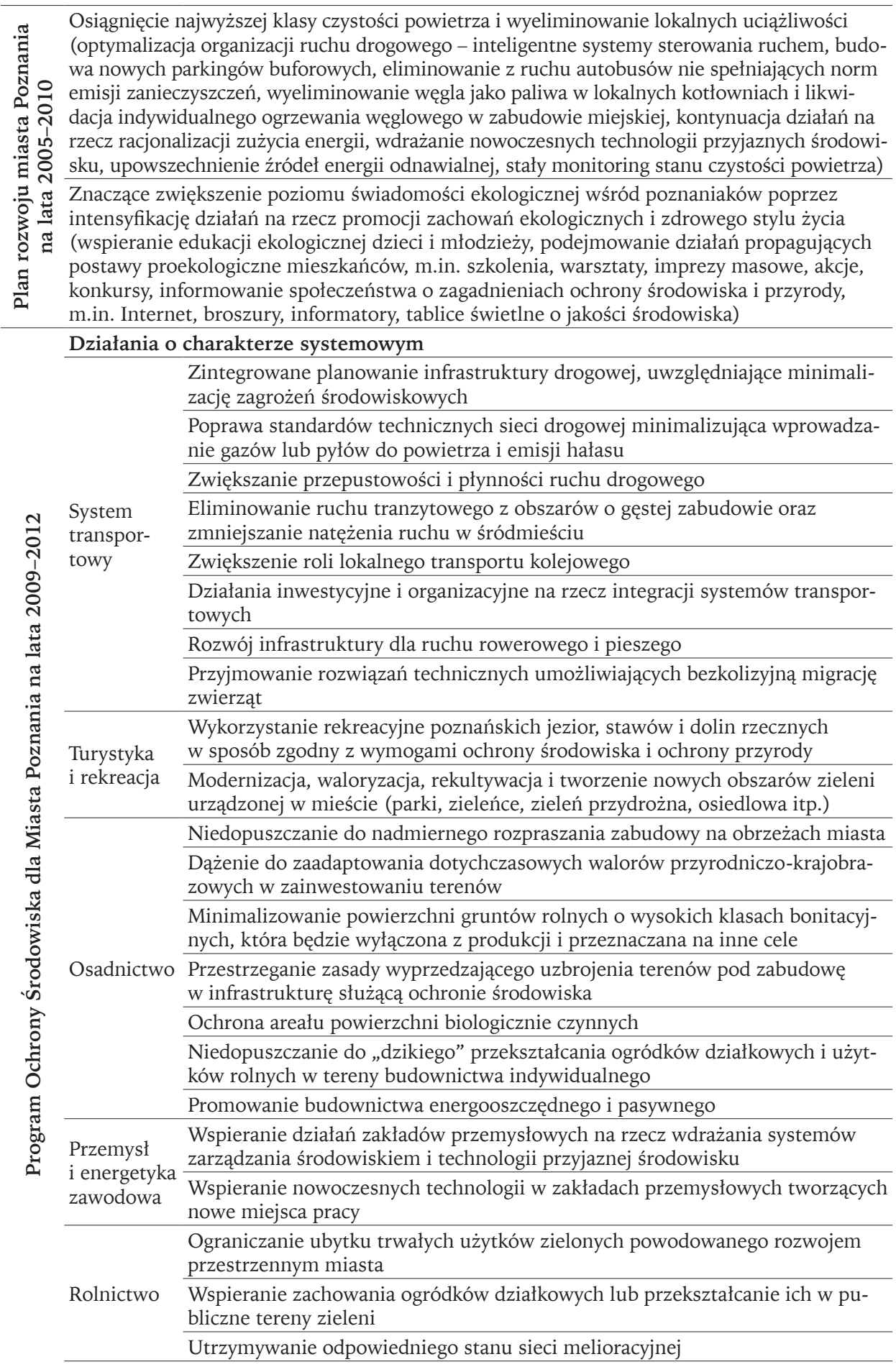


Edukacja ekologiczna w formalnym systemie kształcenia (kontynuacja wsparcia finansowego i organizacyjnego placówek oświatowych przez władze samorządowe, tworzenie i realizacja programów edukacji ekologicznej osadzonych w realiach miasta Poznania, współpraca władz samorządowych z placówkami szkolnymi w zakresie czynnej ochrony przyrody)

Edukacja Edukacja ekologiczna pozaszkolna (imprezy, akcje, konkursy propagujące poekologiczna stawy proekologiczne mieszkańców miasta, kontynuacja i rozwój coraz atrakcyjniejszych form informowania mieszkańców miasta o zasadach dostępu do informacji o środowisku, popularyzacja walorów przyrodniczych miasta i jego problemów środowiskowych, rozwój współpracy władz miasta z podmiotami zewnętrznymi prowadzącymi działalność szkoleniową lub popularyzatorską, rozwój sieci przyrodniczych ścieżek dydaktycznych)

\section{Ochrona dziedzictwa przyrodniczego i racjonalne użytkowanie zasobów przyrody}

System obszarów chronionych (współpraca $z$ władzami rządowymi i organizacjami pozarządowymi we wdrażaniu systemu ochrony obiektów Natura 2000, weryfikacja walorów przyrodniczych istniejących oraz projektowanych obiektów ochrony przyrody, kształtowanie systemu obszarów chronionych miasta Poznania w ciągłości z terenami otaczającymi)

Ochrona fauny i flory (ochrona i reintrodukcja gatunków zagrożonych i ich siedlisk, wprowadzenie przyrodniczego monitoringu środowiska miasta)

Ochrona i utrzymanie terenów zieleni kształtujących krajobrazy miejskie (m.in. zachowanie oraz odtwarzanie ciągłości istniejących elementów pierścieniowo-klinowego układu terenów zieleni miasta, zakładanie nowych parków, zwiększanie zazielenienia terenów osiedlowych i ciągów komunikacyjnych)

Ochrona i utrzymanie lasów (dostosowanie drzewostanów leśnych do warunków siedliskowych oraz antropopresji)

\section{Racjonalne użytkowanie kopalin, ochrona gleb i powierzchni ziemi}

Ochrona powierzchni ziemi (rekultywacja terenów zdewastowanych, przeciwdziałanie nieuzasadnionemu wzrostowi powierzchni uszczelnionej i redukowaniu powierzchni biologicznie czynnej)

Ochrona gleb (ochrona gleb rolniczych - kształtowanie struktury upraw przeciwdziałającej erozji wietrznej, pogarszaniu się struktury gleby i jej zakwaszaniu, upowszechnianie zasad dobrej praktyki rolniczej, minimalizowanie naruszenia powierzchni ziemi $\mathrm{w}$ trakcie realizacji inwestycji budowlanych na terenach wyłączanych z rolniczego użytkowania - działalność kontrolna)

Racjonalne użytkowanie kopalin i przeciwdziałanie ich nielegalnemu pozyskiwaniu

\section{들 Poprawa jakości środowiska i bezpieczeństwa ekologicznego}

Zaopatrzenie w wodę (zmniejszenie zużycia wody m.in. poprzez wspieranie działań podmiotów gospodarczych w zakresie racjonalnego gospodarowania wodą, minimalizację strat wody wodociągowej w sieci przesyłowej m.in. dzięki sukcesywnej wymianie i renowacji wyeksploatowanych odcinków sieci wodociągowej)

Gospodarka ściekowa (całkowite wyeliminowanie zrzutów nieoczyszczonych lub niewystarczająco oczyszczonych ścieków do wód otwartych, wdrożenie systemów podczyszczania ścieków deszczowych, ograniczenie odprowadzania wód opadowych do kanalizacji deszczowej - umożliwianie retencji glebowej)

Stosunki wodne i ochrona przed powodzią (kontrola i utrzymywanie odpowiedniego stanu wałów przeciwpowodziowych Warty i urządzeń wodnych, integracja działań w zakresie ochrony wód z kształtowaniem przestrzeni przyrodniczej - renaturyzacją małych cieków)

Zarządzanie zasobami wodnymi (kontynuacja wdrażania programów ochrony wód w zlewniach rzek: Cybiny i Bogdanki, wdrożenie podobnych programów dla Strumienia Junikowskiego i Różanego Potoku i ewentualnie innych rzek, w miarę rozpoznawania problemów, modernizacja i ochrona ujęć wody) 
Emisja ze źródeł komunikacyjnych (minimalizacja emisji pyłów i gazów - poprawa jakości paliw, promocja i popularyzacja środków transportu zbiorowego, popularyzacja ruchu rowerowego, strefy płatnego parkowania $\mathrm{w}$ centrum miasta, nowe parkingi buforowe, bezwzględne eliminowanie $z$ ruchu pojazdów nie spełniających norm emisji substancji do powietrza, działania edukacyjne dla kształtowania proekologicznych zachowań komunikacyjnych)

Emisja niska (pełne wyeliminowanie węgla jako paliwa w lokalnych kotłowniach oraz likwiI dacja indywidualnego ogrzewania węglowego w zabudowie miejskiej, kontynuacja działań ㄱ. na rzecz oszczędności energii, wykorzystanie rezerw w zakresie integracji gospodarki cieplnej dla ograniczania ilości palenisk indywidualnych)

Energetyka i przemysł (wdrażanie działań mających na celu ograniczenie emisji gazów i pyłów ze źródeł energetycznych, wdrażanie nowoczesnych technologii, przyjaznych środowisku, wzrost wykorzystania lokalnych zasobów odnawialnych źródeł energii - np. energia słoneczna, wodna, wykorzystanie wód geotermalnych, wykorzystanie pomp ciepła)

Zarządzanie jakością powietrza (rozwój monitoringu powietrza, wprowadzanie systemów zarządzania środowiskiem (np. ISO 14001) oraz dobrowolnych działań nienormatywnych - np. czystsza produkcja w zakładach przemysłowych, systematyczna kontrola zakładów przemysłowych)

Ochrona przed hałasem komunikacyjnym (aktualizacja danych o zagrożeniach i monitoring hałasu drogowego w wyznaczonych punktach pomiarowych, opracowanie i realizacja programów ochrony środowiska przed hałasem, wdrażanie rozwiązań inwestycyjnych, w tym technologicznych, o cechach innowacji na rzecz ograniczania hałasu komunikacyjnego u źródła, wdrażanie rozwiązań organizacyjnych na rzecz ograniczenia hałasu komunikacyjnego, wprowadzanie technicznych rozwiązań minimalizujących rozprzestrzenianie się hałasu pasy zieleni ochronnej, ekrany akustyczne Ochrona przed hałasem lotniczym (rozwiązania minimalizujące emisję hałasu lotniczego) Ochrona przed hałasem przemysłowym (eliminacja problemu emisji hałasu do środowiska z obiektów działalności gospodarczej)

Promieniowanie elektromagnetyczne (monitorowanie pól elektromagnetycznych w ramach projektowanych i istniejących systemów, przestrzeganie zapisów zawartych w raportach oddziaływania na środowisko na terenach obszarów dostępnych dla ludności, preferowanie niskokonfliktowych lokalizacji źródeł promieniowania elektromagnetycznego, kontrola wprowadzania do środowiska nowych urządzeń emitujących promieniowanie elektromagnetyczne)

Bezpieczeństwo chemiczne, ekologiczne i zdrowotne (ograniczenie ryzyka wystąpienia zagrożeń środowiska powodowanych funkcjonowaniem podmiotów będących potencjalnym źródłem awarii przemysłowych, zmniejszenie ryzyka wynikającego z transportu materiałów niebezpiecznych, minimalizowanie skutków środowiskowych w przypadku wystąpienia awarii, wykreowanie właściwych zachowań społeczeństwa w sytuacji wystąpienia awarii, doskonalenie systemu zarządzania kryzysowego w aspekcie ochrony środowiska oraz rozwój monitoringu zagrożeń środowiska, eliminacja wyrobów zawierających azbest)

Źródło: opracowanie własne. 